\title{
Internationale bevoegdheid van de Nederlandse rechter en de immuniteit van internationale organisaties
}

\author{
De uitspraak van het Hof van Justitie in Supreme/Supreme Headquarters Allied Powers Europe \\ (SHAPE)
}

Prof. dr. E.C.P.D.C. De Brabandere*

Op 3 september 2020 heeft het Hof van Justitie uitspraak gedaan in de zaak Supreme/Supreme Headquarters Allied Pomers Europe (SHAPE). De zaak heeft betrekking op de internationale bevoegdheid van de Nederlandse rechter inzake een geschil tussen een reeks vennootschappen en een internationale organisatie. Naast de vraag of de Nederlandse rechter internationaal bevoegd is om kennis te nemen van een verzoek door een internationale organisatie tot opheffing van een conservatoir beslag, bespreken het arrest en deze noot de vraag of rekening gehouden moet worden met de immuniteit van executie van internationale organisaties.

Hv7 3 september 2020, zaak C-186/19, ECLI:EU:C: 2020:638 (Supreme/Supreme Headquarters Allied Pomers Europe (SHAPE)).

\section{Inleiding}

Op 3 september 2020 heeft het Hof van Justitie uitspraak gedaan in de zaak Supreme/Supreme Headquarters Allied Pomers Europe (SHAPE) ${ }^{1}$ naar aanleiding van een prejudiciële vraag gesteld door de Hoge Raad der Nederlanden bij arrest van 22 februari 2019, ${ }^{2}$ volgend op een eerdere beslissing van de Hoge Raad in deze zaak. ${ }^{3}$

Prof. dr. E.C.P.D.C. (Eric) De Brabandere is hoogleraar internationale geschillenbeslechting aan Grotius Centre for International Legal Studies en advocaat aan de Balie te Brussel (DMDB Law).

1. HvJ 3 september 2020, zaak C-186/19, ECLI:EU:C:2020:638 (Supreme) Supreme Headquarters Allied Powers Europe (SHAPE)).

2. HR 22 februari 2019, ECLI:NL:HR:2019:292.

3. HR 21 december 2018, ECLI:NL:HR:2018:2361.
De zaak heeft betrekking op de internationale bevoegdheid van de Nederlandse rechter inzake een geschil tussen een reeks vennootschappen (hierna: Supreme) en de Supreme Headquarters Allied Pomers Europe (SHAPE), een internationale organisatie die deel uitmaakt van de NAVO. De zaak gaat enerzijds over de vraag of de Nederlandse rechter internationaal bevoegd is onder Verordening (EU) nr. 1215/2012 (Brussel Ibis $)^{4}$ om kennis te nemen van een verzoek door SHAPE tot opheffing van een conservatoir beslag door Supreme gelegd op SHAPE/NAVO-tegoeden in Brussel (België). Anderzijds schuilt achter die (technische) kwestie de vraag of inzake de internationale bevoegdheid onder Brussel I-bis rekening gehouden moet worden met de immuniteit van executie van internationale organisaties. Dit commentaar gaat voornamelijk in op die laatste dimensie. De aspecten van de zaak die betrekking hebben op de toepassing van Brussel I-bis werden reeds becommentarieerd naar aanleiding van het arrest van de Hoge Raad. ${ }^{5}$ Maar waar nodig zal ook verwezen worden naar de toepassing van Brussel I-bis in het algemeen.

4. Verordening (EU) nr. 1215/2012 van het Europees Parlement en de Raad van 12 december 2012 betreffende de rechterlijke bevoegdheid, de erkenning en de tenuitvoerlegging van beslissingen in burgerlijke en handelszaken (PbEU 2012, L 351/1-32).

5. Zie HR 21 december 2018, ECLI:NL:HR:2018:2361, JOR 2019/73, m.nt. C.G. van der Plas, JIN 2019/26, m.nt. M. Teekens. 


\section{Omstandigheden van de zaak}

SHAPE is een internationale organisatie, opgericht door het Protocol van Parijs, ${ }^{6}$ en is gelieerd aan de NAVO. ${ }^{7}$ SHAPE is gevestigd in België en opereert ook via regionale hoofdkwartieren waaronder het Allied foint Force Command Brunssum (JFCB) gevestigd te Brunssum in Nederland, dat op zich ondergeschikt is aan SHAPE.

Een reeks gelieerde vennootschappen (Supreme), gevestigd in Duitsland, Zwitserland en de Verenigde Arabische Emiraten, heeft op basis van verschillende contracten (Basic Ordering Agreements of BOA's) in 2006 en 2007 onder meer brandstof geleverd aan SHAPE ten behoeve van de ISAF-missie in Afghanistan, gemandateerd door de Veiligheidsraad van de Verenigde Naties $(\mathrm{VN})$.

In 2013 werd beslist om een soort escrom-rekening op te maken bij de Belgische bank BNP Paribas Fortis in Brussel op naam van de NAVO, waarop bedragen door SHAPE en de NAVO-lidstaten die deelnamen aan de ISAF-missie in Afghanistan gestort zouden worden om de nog verschuldigde bedragen aan Supreme te garanderen. Het idee was om na de beëindiging van de contracten in 2014, via een 'Release of Funds Working Group' na te gaan welke bedragen nog verschuldigd zouden zijn aan Supreme en deze dan ook via de escrowrekening uit te betalen. Onder meer omdat Supreme door NAVO en SHAPE beschuldigd wordt van fraude ${ }^{8}$ werden geen betalingen goedgekeurd aan Supreme vanuit de escrowrekening.

De grond van de zaak, namelijk de vraag of Supreme aanspraak kan maken op de gelden op de escrowrekening, werd recent beslecht in beroep door het gerechtshof 's-Hertogenbosch. ${ }^{9}$ Het gerechtshof heeft zich in die zaak onbevoegd verklaard om kennis te nemen van het geschil tussen Supreme en SHAPE en JFCB omdat die laatste twee genieten van immuniteit van jurisdictie en bijgevolg niet voor een nationale rechter gedaagd kunnen worden. Dit arrest is van belang voor de link tussen de immuniteit van SHAPE en de kwalificatie van de leveringscontracten (BOA's); ik kom hier later op terug.

De uitspraak van het Hof van Justitie echter heeft betrekking op een parallelle procedure betreffende een conservatoir derdenbeslag dat door Supreme gelegd werd op de escrowrekening bij BNP Paribas Fortis in Brussel.

Supreme had bij beschikking van de voorzitter van de rechtbank Limburg in 2016 verlof gekregen voor een conservatoir derdenbeslag op de tegoeden van de escrowrekening, en dit voor een bedrag van USD 217.857.167. SHAPE en JFCB hadden hiertegen beroep

6. Protocol on the Status of International Military Headquarters set up pursuant to the North Atlantic Treaty' 28 augustus 1952 (Trb. 1953, 11).

7. Zie A.B. Muñoz Mosquera, 'The North Atlantic Treaty: Article 9 and NATO's Institutionalization', Emory International Law Review 2019, special, p. 149

8. Zie HR 22 februari 2019, ECLI:NL:HR:2019:292, r.o. 3.1 (viii).

9. Hof 's-Hertogenbosch 10 december 2019, ECLI:NL:GHSHE:2019:4464. aangetekend op basis van de immuniteit van executie van de internationale organisatie. De rechtbank Limburg had in eerste aanleg anvaard dat SHAPE en JFCB zich konden beroepen op immuniteit van executie en derhalve de opheffing van het beslag bevolen. De rechtbank Limburg had eveneens Supreme verboden verder beslag te leggen op de escrowrekening. ${ }^{10}$ Deze beslissing werd door het gerechtshof 's-Hertogenbosch op 27 juni 2017 bevestigd. ${ }^{11}$ Supreme is vervolgens in cassatie gegaan van die laatste beslissing. Het is in het kader van het cassatieberoep voor de Hoge Raad dat een prejudiciële vraag gesteld werd aan het Hof van Justitie.

\section{Prejudiciële vraag van de Hoge Raad}

De Hoge Raad oordeelde dat, alhoewel partijen niet betwist hadden dat de Nederlandse rechter internationaal bevoegd is om kennis te nemen van het geschil op grond van artikel 35 Brussel I-bis, hetgeen het gerechtshof 's-Hertogenbosch aangenomen had, ${ }^{12}$ het gepast was om ambtshalve te onderzoeken of de rechtbanken van een andere EU-lidstaat krachtens artikel 24 Brussel I-bis exclusief bevoegd zouden zijn. Artikel 35 Brussel I-bis stipuleert: 'In de wetgeving van een lidstaat vastgestelde voorlopige of bewarende maatregelen kunnen bij de gerechten van die staat worden aangevraagd, zelfs indien een gerecht van een andere lidstaat bevoegd is om van het bodemgeschil kennis te nemen.' Artikel 24 lid 5 Brussel I-bis stipuleert daarentegen: 'Ongeacht de woonplaats van partijen zijn bij uitsluiting bevoegd: voor de tenuitvoerlegging van beslissingen: de gerechten van de lidstaat van de plaats van tenuitvoerlegging.' Met andere woorden, indien de vordering betrekking zou hebben op de tenuitvoerlegging van beslissingen zou, aldus artikel 24 lid 5 Brussel I-bis, de Belgische rechter bevoegd zijn. Voorlopige of bewarende maatregelen onder Nederlands recht zouden echter volgens artikel 35 Brussel I-bis kunnen worden aangevraagd bij de Nederlandse rechter.

Omdat SHAPE aanvoerde dat het recht heeft op immuniteit van executie, was het volgens de Hoge Raad van belang eerst uit te maken of de vordering aangemerkt kon worden als een burgerlijke of handelszaak onder Brussel I-bis. ${ }^{13}$ Artikel 1 Brussel I-bis voorziet expliciet dat 'de aansprakelijkheid van de staat wegens een handeling of nalaten in de uitoefening van het openbaar gezag (acta jure imperii)' uitgesloten is van het toepassingsgebied van de verordening.

De Hoge Raad besliste om verschillende prejudiciële vragen voor te leggen aan het Hof van Justitie. ${ }^{14}$ De eer-

10. Rb. Limburg 12 juni 2017, ECLI:NL:RBLIM:2017:5606.

11. Hof 's-Hertogenbosch 27 juni 2017, ECLI:NL:GHSHE:2017:2860.

12. Hof 's-Hertogenbosch 27 juni 2017, ECLI:NL:GHSHE:2017:2860, r.o. 3.7.

13. Art. 1 Brussel I-bis.

14. HR 22 februari 2019, ECLI:NL:HR:2019:292, r.o. 6. 
ste vraag was of de vordering van SHAPE (de opheffing van het gelegd conservatoir derdenbeslag en het verbod om een nieuw beslag te leggen op basis van de immuniteit van SHAPE) aangemerkt moet worden als een 'burgerlijke of handelszaak' als bedoeld in artikel 1 lid 1 Brussel I-bis, rekening houdend met het gegeven dat het beslag betrekking had op een contractueel geschil over de betaling voor de levering van brandstoffen ten behoeve van de ISAF-missie uitgevoerd door de NAVO.

Indien de eerste vraag bevestigend beantwoord zou worden, werd het Hof van Justitie gevraagd of artikel 24 lid 5 Brussel I-bis aldus moet worden uitgelegd dat de rechtbanken waar een conservatoir derdenbeslag is gelegd bij uitsluiting bevoegd zijn om kennis te nemen van een vordering tot opheffing van dat beslag, zelfs al is dat beslag gelegd met verlof van de rechter in een andere lidstaat. Ook hierbij werd de vraag gesteld of rekening gehouden moet worden met de immuniteit van SHAPE.

De derde vraag luidde of de Nederlandse rechter bij de beantwoording van de twee eerste vragen moet nagaan of het beroep op immuniteit van executie gegrond is, en welke gegevens hierbij in aanmerking genomen moeten worden.

\section{Arrest van het Hof van Justitie van 3 september 2020}

De eerste vraag was of de vordering van SHAPE aangemerkt moet worden als een 'burgerlijke of handelszaak' als bedoeld in artikel 1 lid 1 Brussel I-bis. Het Hof van Justitie splitst zijn antwoord op deze vraag in drie punten. Deze drie punten zijn: (1) of de aard van de in het hoofdgeding ingestelde vordering in kort geding een gevolg heeft voor de kwalificatie van die vordering als 'burgerlijke of handelszaak', (2) welke criteria in de rechtspraak zijn vastgesteld voor die kwalificatie, en (3) of de immuniteiten van SHAPE hierbij een rol spelen.

Met betrekking tot het eerste punt stelt het Hof van Justitie dat 'de aard van de rechten ter waarborging waarvan de maatregelen in wezen bedoeld zijn' doorslaggevend is voor de vraag of bewarende maatregelen onder de werkingssfeer van Brussel I-bis vallen. ${ }^{15}$ De aard van de verzochte maatregelen noch de kenmerken van het geding ten gronde zijn dus van belang.

Vervolgens gaat het Hof van Justitie na welke criteria gebruikt moeten worden om na te gaan of een vordering kwalificeert als 'burgerlijke of handelszaak'. Het Hof van Justitie stelt dat gekeken moet worden naar 'de aard van de rechtsbetrekkingen tussen de procespartijen of het voorwerp van het geschil dan wel de grondslag van de ingestelde vordering en de regels voor het geldend maken ervan'. ${ }^{16}$ Als door een van de partijen (een 'overheidsorgaan') bij een geding bevoegdheden van open-

15. Supreme, punt 54.

16. Supreme, punt 55. baar gezag worden uitgeoefend (acta jure imperii), valt dit bijgevolg niet binnen de werkingssfeer van Brussel Ibis. ${ }^{17}$ Dit volgt letterlijk uit de tekst van artikel 1 lid 1 Brussel I-bis. Geschillen tussen overheidsinstanties en een particulier die betrekking hebben op zogenoemde acta iure gestionis, zijnde handelingen van de overheid die niet vallen onder de uitoefening van het 'openbaar gezag', vallen echter wel binnen het toepassingsgebied van Brussel I-bis.

Vervolgens komt de vraag of het feit dat een internationale organisatie zich in het kader van een geschil beroept op immuniteit van executie, betekent dat dit geschil niet valt onder het toepassingsgebied van Brussel I-bis. Het Hof van Justitie herhaalt eerst dat de jurisdictionele immuniteit van staten niet absoluut is, en enkel geldt indien het geschil betrekking heeft op acta iure imperii (soevereine handelingen). ${ }^{18}$ Wat acta iure gestionis betreft: deze vallen in beginsel niet onder de jurisdictionele immuniteit van staten. Het Hof van Justitie verwijst hier naar zijn uitspraak in de Rina-zaak, waarin dit beginsel ook werd toegepast. In diezelfde zaak had het Hof van Justitie gesteld dat een privaatrechtelijke organisatie (en dus geen internationale organisatie) zich ook niet kan beroepen op de immuniteit van staten indien deze geen bevoegdheden van openbaar gezag uitoefent, zelfs als die organisatie een activiteit uitoefent die haar door een staat werd gedelegeerd. ${ }^{19}$

Het Hof van Justitie stelt in de Supreme-zaak dat deze rechtspraak kan worden toegepast in het geval de immuniteit door een internationale organisatie wordt ingeroepen, 'ongeacht of het gaat om immuniteit van rechtsmacht dan wel om immuniteit van executie' en niettegenstaande het feit dat de immuniteit van internationale organisaties een andere grondslag heeft dan de immuniteit van staten. ${ }^{20}$ De immuniteit van staten is immers gebaseerd is op het beginsel 'par in parem non habet imperium', de soevereine gelijkheid van staten, terwijl de immuniteit van internationale organisaties gestoeld is op het principe van functionalisme (vgl. hierna). Het feit dat een internationale organisatie zich voor een nationale rechtbank beroept om immuniteit staat, aldus het Hof van Justitie, niet automatisch eraan in de weg dat Brussel I-bis van toepassing is. ${ }^{21}$

Het Hof van Justitie stelt vervolgens dat nagegaan moet worden of een geschil waarbij een internationale organisatie betrokken is en die onder het toepassingsgebied van Brussel I-bis zou vallen, betrekking heeft op de uitoefening door die organisatie van 'bevoegdheden van openbaar gezag' ${ }^{22}$ Toegepast of de feiten van deze zaak stelt het Hof van Justitie dat, alhoewel dit geschil onrechtstreeks betrekking heeft op een militaire operatie ter handhaving van de vrede en veiligheid, de rechtsbe-

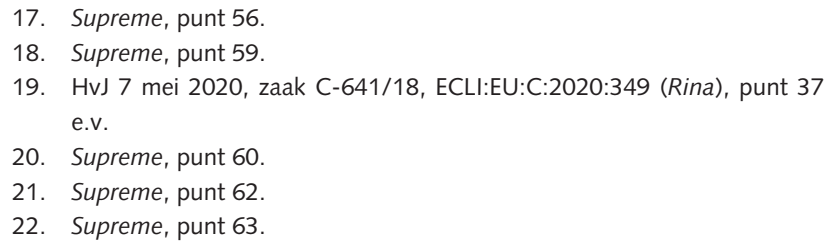


trekking tussen partijen 'privaatrechtelijk' is. ${ }^{23}$ Het openbaar doel van de militaire operatie in Afghanistan is op zich onvoldoende om die activiteiten als acta iure imperii te kwalificeren, 'voor zover zij niet overeenstemmen met de uitoefening van bevoegdheden die buiten het bestek van de voor betrekkingen tussen particulieren geldende regels vallen'. ${ }^{24}$ Het Hof van Justitie concludeert dat de vordering binnen de werkingssfeer van deze verordening valt. ${ }^{25}$

De tweede vraag betrof de vraag in welke mate Brussel I-bis aldus uitgelegd moet worden dat de vordering in kwestie onder de exclusieve bevoegdheid valt van de gerechten van de lidstaat waar het conservatoir derdenbeslag ten uitvoer is gelegd. Dienaangaande oordeelt het Hof van Justitie dat een dergelijke vordering 'niet als zodanig betrekking heeft op de tenuitvoerlegging van beslissingen' in de zin van artikel 24 lid 5 Brussel I-bis, en dus niet binnen de werkingssfeer van deze bepaling valt. ${ }^{26}$ Een dergelijke vordering valt dus niet onder de exclusieve bevoegdheid van de gerechten van de lidstaat waarin het conservatoir derdenbeslag ten uitvoer is gelegd. Het Hof van Justitie merkt ook op dat de vraag of een internationale organisatie zich kan beroepen op immuniteit van executie, op zich niet inhoudt dat een rechtbank niet moet nagaan of zij bevoegd is op grond van Brussel I-bis. De immuniteit van executie, met andere woorden, wordt pas vastgesteld nadat 'de internationale bevoegdheid van dat gerecht is vastgesteld' ${ }^{27}$

\section{Bespreking}

De prejudiciële vragen die het Hof van Justitie heeft moeten beantwoorden lijken eerder technische vragen die voornamelijk betrekking hebben op de internationale bevoegdheid van rechtbanken onder Brussel I-bis. De tweede vraag is dat inderdaad, en het Hof van Justitie kan zeker gevolgd worden in zijn interpretatie van Brussel I-bis dat de vordering van SHAPE op zich geen betrekking heeft 'op de tenuitvoerlegging van beslissingen' in de zin van artikel 24 lid 5 Brussel I-bis.

Achter de eerste vraag schuilt echter de fundamentele vraag die betrekking heeft op de draagwijdte van de immuniteit van executie van internationale organisaties in het algemeen, en de toepassing van Brussel I-bis op geschillen met internationale organisaties waarbij de organisatie in kwestie zich beroept op haar immuniteit van executie. Op die vraag zal ik deze bespreking verder richten.

\section{Vallen vorderingen tegen internationale}

organisaties onder Brussel I-bis?

Voorafgaand dient opgemerkt te worden dat Brussel Ibis in artikel 1 lid 1 alleen de aansprakelijkheid van een

\footnotetext{
23. Supreme, punt 65.

24. Supreme, punt 66

25. Supreme, punt 68

26. Supreme, punt 73

27. Supreme, punt 74
}

staat wegens een handeling of nalaten in de uitoefening van het openbaar gezag (acta jure imperii) uitsluit van de werkingssfeer van de verordening. Naar de letter van Brussel I-bis is er dus geen uitzondering voor de aansprakelijkheid van internationale organisaties voor handelingen gesteld in de uitoefening van het openbaar gezag.

Ten tweede, Brussel I-bis heeft tot doel 'de rechterlijke bevoegdheid, de erkenning en de tenuitvoerlegging van beslissingen in burgerlijke en handelszaken' te regelen. Of een staat of een internationale organisatie al dan niet immuniteit geniet, wordt dus niet geregeld door de verordening. De uitsluiting van de aansprakelijkheid van een staat wegens een handeling of nalaten in de uitoefening van het openbaar gezag houdt dus niet in dat de staat daarvoor per definitie immuniteit heeft, maar is wel de grondslag van de uitsluiting. Dit kan men ook afleiden uit de rechtspraak van het Hof van Justitie. Het onderscheidend criterium dat het Hof van Justitie voor de toepassing van Brussel I-bis hanteert ('uitoefening van het openbaar gezag') lijkt sterk op de maatstaf die gebruikt wordt om het onderscheid te maken tussen acta jure imperii en acta jure gestionis. Het onderscheid tussen handelingen acta jure imperii en acta jure gestionis wordt gemaakt op basis van de vraag of de handeling of activiteit in kwestie al dan niet soeverein is, ${ }^{28}$ of gesteld is in de uitoefening van het openbaar gezag. ${ }^{29}$ Tegelijkertijd is het niet geheel duidelijk of acta jure imperii geen 'burgerlijke en handelszaken' zijn onder artikel 1 lid 1 Brussel I-bis, of daar principieel wel onder vallen, maar er expliciet van uitgesloten zijn. ${ }^{30}$

Het Hof van Justitie kan gevolgd worden in de principiele stelling dat de internationale bevoegdheid van een nationale rechter een vraag is die eerst beantwoord moet worden, alvorens nagegaan kan worden of de immuniteit van executie van de organisatie terecht ingeroepen kan worden. Dat een rechter zich internationaal bevoegd verklaart, doet geen afbreuk aan de bescherming van de immuniteit waarop een internationale organisatie zich beroept.

De principiële stelling dat een geschil waarbij een internationale organisatie betrokken is, uitgesloten is van het toepassingsgebied van Brussel I-bis als die betrekking heeft op de uitoefening door die organisatie van 'bevoegdheden van openbaar gezag' 31 is ook verdedig-

28. M. Shaw, International Law, Cambridge: Cambridge University Press 2017, p. 532

29. Ter vergelijking: het Verdrag van de Verenigde Naties inzake de immuniteit van rechtsmacht van staten en hun eigendommen (New York, 2 december 2004, http://verdragenbank.overheid.nl/verdragen/ 010995), dat nog niet in werking is getreden, voorziet dat immuniteit niet geldt voor 'commerciële transacties' waarbij volgens art. 2 lid 1 onder c van dat verdrag een 'commerciële transactie' omschreven wordt als 'i. elke commerciële overeenkomst of transactie voor de verkoop van goederen of levering van diensten; ii. elke overeenkomst ter zake van een lening of een andere transactie van financiële aard, met inbegrip van elke verplichting tot garantstelling of vrijwaring ter zake van een dergelijke lening of transactie; iii. elke andere overeenkomst of transactie van commerciële, industriële, zakelijke of professionele aard, met uitzondering van arbeidsovereenkomsten van personen.'

30. Rina, punt 49.

31. Supreme, punt 63. 
baar. De uitoefening van 'bevoegdheden van openbaar gezag' rechtvaardigt in se de uitsluiting onder Brussel Ibis, niet noodzakelijkerwijs het feit dat het de handeling van een staat is. Anderzijds gaat het parallellisme tussen internationale organisaties en staten niet helemaal op en het is precies op dit punt dat de analyse van het Hof van Justitie betreffende de vraag of de transactie in kwestie valt onder de uitoefening van 'bevoegdheden van openbaar gezag' door SHAPE, mijns inziens tekortschiet.

Kunnen de 'brandstofleveringen' losgekoppeld worden van de ISAF-missie in Afghanistan?

Betreffende de kwalificatie van de handeling stelt het Hof van Justitie dat, niettegenstaande deze betrekking heeft op een militaire operatie ter handhaving van de vrede en veiligheid, de rechtsbetrekkingen tussen partijen 'privaatrechtelijk' zijn. ${ }^{32}$ Het Hof van Justitie stelt dat het openbaar doel van bepaalde activiteiten, de militaire operatie in Afghanistan, op zich niet voldoende is om die activiteiten als acta iure imperii te kwalificeren. ${ }^{33}$ Alhoewel de nationale rechter moet nagaan of het effectief gaat om acta iure imperii, is het merkwaardig dat het Hof van Justitie hier redelijk summier poneert dat het feit dat de brandstoffen die het voorwerp waren van de overeenkomst tussen SHAPE en Supreme gebruikt werden voor een militaire operatie, niet resulteert in de kwalificatie van die overeenkomsten als aangegaan door SHAPE in 'de uitoefening van bevoegdheden van openbaar gezag'.

De conclusie van het Hof van Justitie weerspiegelt de conclusie van advocaat-generaal Henrik Saugmandsgaard Øe, die stelt dat de 'contractuele betrekking niet wordt gekenmerkt door een uiting van openbaar gezag'. ${ }^{34}$ Dit volgt, aldus de advocaat-generaal, uit het feit dat 'de verplichtingen tussen de partijen vrijelijk zijn overeengekomen', en de overeenkomsten 'tegen marktvoorwaarden zijn gesloten na een aanbestedingsprocedure'. ${ }^{35}$ Advocaat-generaal Saugmandsgaard Øe stelt eveneens, en wordt hierin gevolgd door het Hof van Justitie, dat het feit dat de brandstoffen door Supreme geleverd bestemd waren voor een door de NAVO geleide militaire operatie hieraan geen afbreuk doet. ${ }^{36}$ Het 'uiteindelijke gebruik van de geleverde brandstoffen door SHAPE' heeft, aldus de advocaatgeneraal, 'geen invloed op de contractuele rechtsbetrekking tussen partijen'. ${ }^{37}$

Deze zienswijze moet mijns inziens genuanceerd worden, en voornamelijk omdat de vraag gesteld moet worden of onderliggende transacties effectief losgekoppeld kunnen worden van de uiteindelijke activiteit waarvoor deze transacties bedoeld zijn.

De aankoop van brandstoffen via een reeks raamovereenkomsten staat niet op zichzelf; het is immers niet zo

32. Supreme, punt 65.

33. Supreme, punt 66.

34. Conclusie A-G 2 april 2020, zaak C-186/19, ECLI:EU:C:2020:252 (Supreme/Supreme Headquarters Allied Powers Europe (SHAPE)), punt 100.

35. Conclusie A-G, Supreme, punt 101

36. Conclusie A-G, Supreme, punt 102

37. Conclusie A-G, Supreme, punt 103. dat SHAPE brandstoffen aankocht, zelfs aan marktvoorwaarden, om als het ware zelf de brandstoffen te verhandelen als deelnemer in de handelsmarkt als een private of commerciële entiteit. De brandstoffen waren bestemd voor gebruik door militaire voertuigen en vliegtuigen in het kader van een door de VN-Veiligheidsraad gemandateerde operatie onder Hoofdstuk VII van het VNHandvest. De militaire operatie, die zonder meer valt onder de definitie 'openbaar gezag', kan onmogelijk plaatsvinden zonder het gebruik van privaatrechtelijke instrumenten om, onder meer, brandstoffen te leveren. Het feit dat het gerechtshof 's-Hertogenbosch zich onbevoegd heeft verklaard om kennis te nemen van het geschil tussen Supreme en SHAPE en JFCB omdat die laatste twee genieten van immuniteit van jurisdictie, lijkt dit te bevestigen. ${ }^{38}$ Het gerechtshof stelt expliciet dat

'Het aanschaffen van brandstoffen in relatie tot de ISAF activiteiten, als te leveren in het betreffende operatiegebied in Afghanistan en daarbuiten houdt onmiddellijk verband met de vervulling van de taak van SHAPE en JFCB in het kader van ISAF, dus er is onverkort sprake van functionele immuniteit. Dat voor Supreme sprake was en is van een commercieel contract makt de context van de leveranties niet anders. ${ }^{39}$

Dat een door de VN-Veiligheidsraad gemandateerde operatie onder Hoofdstuk VII van het VN-Handvest valt onder de uitoefening van openbaar gezag lijdt weinig twijfel. ${ }^{40}$ Wat betreft in het bijzonder de leveringscontracten, is de zaak ingewikkelder. Het Hof van Justitie neemt de stelling in dat alleen rekening gehouden moet worden met de aard van de handeling en niet met het uiteindelijke doel. Sommige auteurs zijn eveneens van oordeel dat leveringscontracten met staten, ook voor militaire goederen, in principe als commerciële transacties gekwalificeerd dienen te worden. ${ }^{41}$ Deze zienswijze verdient nuance, vooral als deze betrekking heeft op activiteiten van internationale organisaties.

Ten eerste wordt het principe dat een contract op zichzelf beschouwd moet worden, niet door iedereen gedeeld. Zoals gesteld door Yas Banifatemi: 'a simple sale contract may look entirely different if one enquires into the intended use of the purchased goods'. ${ }^{42}$

38. Hof 's-Hertogenbosch 10 december 2019, ECLI:NL:GHSHE:2019:4464.

39. Hof 's-Hertogenbosch 10 december 2019, ECLI:NL:GHSHE:2019:4464, r.o. 6.7.9.2.

40. X. Yang, State Immunity in International Law, Cambridge: Cambridge University Press 2017, p. 83. Dienaangaande kan verwezen worden naar de zaak Stichting Mothers of Srebrenica waar het Europees Hof voor de Rechten van de Mens gesteld heeft dat de VN immuniteit geniet voor een vredesoperatie onder Hoofdstuk VII van het VN-Handvest, en dus impliciet bevestigt dat de handeling valt onder de uitoefening van het openbaar gezag (EHRM 11 juni 2013, appl.nr. 65542/12 (Stichting Mothers of Srebrenica e.a./Netherland), punt 154).

41. Yang 2017, p. 77

42. Y. Banifatemi, 'Jurisdictional Immunity of States - Commercial Transactions', in: T. Ruys, N. Angelet, \& L. Ferro (red.), The Cambridge Hand- 
Ten tweede worden militaire goederen vaak gedekt door de immuniteit van jurisdictie en/of immuniteit van executie, ${ }^{43}$ wat dus in principe inhoudt dat dergelijk eigendommen beschouwd worden als eigendommen gebruikt voor acta jure imperii. Militaire goederen worden bijvoorbeeld in het VN Verdrag inzake Staatsimmuniteit expliciet gecategoriseerd als eigendommen gebruikt voor niet-commerciële overheidsdoeleinden en dit strekt zich uit tot goederen die niet alleen worden gebruikt maar ook beoogd zijn voor de uitoefening van militaire taken. ${ }^{44}$ Dergelijks goederen vallen expliciet onder de immuniteit van executie van staten. Dit zegt natuurlijk niet expliciet iets over de aanschaffing van die goederen, maar is wel een indicatie dat militaire goederen, inclusief brandstof, niet evident 'commerciële' goederen zijn. Ten derde kan een parallel gemaakt worden met arbeidsovereenkomsten tussen internationale organisaties en private personen. Dergelijke overeenkomsten zijn, als men louter naar de aard van de handeling kijkt, contractueel en privaatrechtelijk van aard. Maar arbeidsovereenkomsten worden eveneens (in de meeste gevallen) beschouwd als een handeling in de uitoefening van het openbaar gezag omdat ze onlosmakelijk verbonden zijn met de algemene bevoegdheden van een internationale organisatie. In dergelijke zaken heeft ook het Europees Hof voor de Rechten van de Mens herhaaldelijk bevestigd dat immuniteit principieel geldt, en dus dat arbeidscontracten vallen onder 'uitoefening van openbaar gezag'. ${ }^{45}$

Om die redenen lijkt het me dat het louter kijken naar de intrinsieke kenmerken van een overeenkomst om deze al dan niet te kwalificeren als een handeling gesteld in de uitoefening van het openbaar gezag, afbreuk doet aan de complexiteit van de vraag.

Het parallelisme tussen de immuniteit van staten en van internationale organisaties

Een tweede punt waar de analyse van Hof van Justitie mijns inziens tekortschiet, heeft betrekking op de gelijkstelling van de immuniteiten en handelingen van internationale organisaties met die van staten. Het Hof van Justitie stelt immers dat de rechtspraak inzake de immuniteit van rechtsmacht van staten kan worden toegepast in het geval waarin de immuniteit door een internationale organisatie wordt ingeroepen. ${ }^{46}$

Het Hof van Justitie oordeelt niet expliciet dat in dit geval SHAPE geen immuniteit geniet in deze zaak, omdat dit uiteindelijk door de nationale rechter beslist moeten worden. Het Hof van Justitie stelt ook dat het

book of Immunities and International Law, Cambridge: Cambridge University Press, p. 125-141, op p. 127.

43. A. Reinisch, 'European Court Practice Concerning State Immunity from Enforcement Measures', European Journal of International Law 2006, nr. 4, p. 825

44. Art. 21 lid 1 onder $b$ Verdrag van de Verenigde Naties inzake de immuniteit van rechtsmacht van staten en hun eigendommen (New York, 2 december 2004, http://verdragenbank.overheid.nl/verdragen/ 010995) (niet in werking getreden).

45. Zie bijv. EHRM 12 mei 2009, appl.nr. 10750/03 (Gasparini/België en Italië) en EHRM 5 maart 2013, appl.nr. 39619/06 (Richard Chapman/ België).

46. Supreme, punt 60 . enkele feit dat de nationale rechter zich internationaal bevoegd verklaart, geen afbreuk doet aan de bescherming van de immuniteit van de internationale organisatie. $^{47}$

Tegelijk is de bespreking van de immuniteit van SHAPE door het Hof van Justitie nodig omdat het oordeelde dat de vraag of de vordering van SHAPE aangemerkt moet worden als een 'burgerlijke of handelszaak' toch (deels) beinvloed wordt door de vraag of de immuniteiten van SHAPE hierbij een rol spelen. Het arrest van het Hof van Justitie is hier niet erg duidelijk over, maar het Hof van Justitie lijkt te stellen dat de kwestie van de immuniteit een rol speelt in het kader van de analyse of een handeling in de uitoefening van het openbaar gezag gesteld werd:

'Om te bepalen of een geding waarbij een internationale organisatie is betrokken die een beroep heeft gedaan op immuniteit van executie al dan niet binnen de materiële werkingssfeer van die verordening valt, moet bijgevolg worden onderzocht of die organisatie, gelet op de in punt 55 van dit arrest genoemde criteria, bevoegdheden van openbaar gezag uitoefent.' $^{48}$

Het Hof van Justitie lijkt er dus van uit te gaan dat alleen als het inroepen van de immuniteit samengaat met een handeling gesteld in de uitoefening van het openbaar gezag, een dergelijke handeling buiten de werkingssfeer van Brussel I-bis valt, waarbij het criterium 'openbaar gezag' blijkbaar doorslaggevend is. In principe is dus het inroepen van immuniteit niet relevant. Maar het Hof van Justitie gaat wel in op die kwestie. De reden lijkt te zijn dat volgens het Hof van Justitie de voor staten geldende binaire categorisatie van handelingen als acta jure imperii of acta jure gestionis bijna perfect samenvalt met de toepassing (of niet) van de immuniteit van staten, waardoor een uitspraak over het laatste iets zegt over het eerste.

Deze categorisatie overhevelen naar internationale organisaties is echter niet evident, omdat precies beide categorieën (acta jure imperii of acta jure gestionis en immuniteit of niet) in het geval van internationale organisaties niet overeenkomen. Het Hof van Justitie stelt terecht dat de immuniteit van Staten gebaseerd is op het beginsel 'par in parem non habet imperium', de soevereine gelijkheid van staten, terwijl de immuniteit van internationale organisaties gestoeld is op het principe van functionalisme, maar precies om die reden kunnen de principes van toepassing op staten niet zomaar toepast worden op internationale organisaties. De vraag of de handeling in kwestie valt onder het 'openbaar gezag', en de vraag of een internationale organisatie immuniteit geniet, kan niet op eenzelfde analogische manier beantwoord worden, zoals dit het geval is bij staten.

De redenen voor het verlenen van immuniteit aan internationale organisaties zijn niet vergelijkbaar met de

47. Supreme, punt 64.

48. Supreme, punt 63. 
redenen die ten grondslag liggen aan staatsimmuniteit. De immuniteit van staten is gebaseerd op de soevereine gelijkheid van staten - de rechtbanken van een staat kunnen niet oordelen over de handelingen van een andere staat. De toekenning van immuniteiten aan internationale organisaties is gebaseerd op functionele criteria en heeft voornamelijk als doel de onafhankelijkheid van de organisatie te verzekeren en haar in staat te stellen haar functies te vervullen zonder inmenging van de rechtbanken van de lidstaten. ${ }^{49}$

Het is algemeen aanvaard dat internationale organisaties, op basis van die functionele criteria, in beginsel absolute immuniteit genieten voor alle handelingen die ze stellen. ${ }^{50}$ Er kan slechts eventueel sprake zijn van enkele zeer beperkte uitzonderingen, zoals ultra vires handelingen. Dit geldt voor de immuniteit van jurisdictie van internationale organisaties, en misschien zelfs sterker voor de immuniteit van executie van internationale organisaties. ${ }^{51}$

De absolute immuniteit van executie volgt uit de verdragsbepalingen die de immuniteit van executie van internationale organisaties expliciet en zonder uitzonderingen vastleggen. Verdragen verlenen gewoonlijk immuniteit tegen elke vorm van juridische procedure en beschermen alle 'fondsen, activa en andere eigendommen' van de organisatie tegen elke vorm van uitvoerende of bewarende maatregelen. Zo ook artikel XI van het Protocol van Parijs dat de SHAPE oprichtte:

'No measure of execution or measure directed to the seizure or attachment of its property or funds shall be taken against any Allied Headquarters, except for the purposes of paragraph 6 a. of Article VII and Article XIII of the Agreement.'

Uitzonderlijk vindt men uitsluitingen aan de immuniteit van executie van internationale organisaties, maar deze zijn beperkt tot specifieke situaties en categorieën organisaties. Uitzonderingen in het kader van de tenuitvoerlegging van rechterlijke uitspraken worden soms expliciet voorzien in statuten, maar deze zijn voornamelijk beperkt tot internationale financiele organisaties, zoals de Wereldbank of de Bank for International Settlements. ${ }^{52}$ Een tweede type uitzondering vindt men soms terug betreffende beslaglegging op de salarissen van medewer-

49. Zie E.H. Fedder, 'The Functional Basis of International Privileges and Immunities: A New Concept in International Law and Organisation', American University Law Review 1960, afl. 9, p. 64.

50. K.E. Boon, 'Immunities of the United Nations and Specialised Agencies', in: Ruys, Angelet \& Ferro 2019, p. 201.

51. E. De Brabandere, 'Measures of Constraint and the Immunity of International Organisations', in: Ruys, Angelet \& Ferro 2019, p. 327.

52. Art. VII Articles of Agreement of the International Bank for Reconstruction and Development, 27 december 1945, beschikbaar via http:// siteresources.worldbank.org/EXTABOUTUS/Resources/ibrdarticlesofagreement.pdf. Zie ook Chapter VIII, Agreement Establishing the European Bank for Reconstruction and Development, 29 mei 1990, beschikbaar via www.ebrd.com/news/publications/institutionaldocuments/basic-documents-of-the-ebrd.html en art. 55 lid 2 Statutes of the Bank for International Settlements, 20 januari 1930 (gewijzigd op 7 november 2016), beschikbaar via www.bis.org/about/statutesen.pdf. kers van de organisatie. Tot slot worden uitzonderingen soms ook voorzien voor claims van derden voor schade in het kader van verkeersongevallen. ${ }^{53}$

Alhoewel sommige auteurs en rechterlijke uitspraken een uitzondering lijken te maken op de immuniteit van executie van internationale organisaties voor eigendommen en activa gebruikt voor commerciële doeleinden, ${ }^{54}$ bevestigt de rechtsleer in het algemeen het absolute karakter van de immuniteit van executie van internationale organisaties. ${ }^{55}$ De rechtspraak bevestigt ook in grote mate het absolute karakter van de immuniteit van executie van internationale organisaties, zowel internationaal $^{56}$ als in Nederland. ${ }^{57}$

Zoals gezegd, het Hof van Justitie oordeelt niet expliciet dat in dit geval SHAPE geen immuniteit geniet in deze zaak. Maar de overweging dat de rechtspraak inzake de immuniteit van rechtsmacht van staten kan worden toegepast op de immuniteit door een internationale organisatie is niet begrijpelijk, en was mijns inziens ook niet nodig. Wat staten betreft, is het relatief eenvoudig(er) om ervan uit te gaan dat als een handeling gesteld is in de uitoefening van het openbaar gezag, deze immuniteit geniet, en vice versa. Het inroepen door een staat van immuniteit, indien terecht, valt dan samen met de uitsluiting van de toepassing van Brussel I-bis. Maar dit gaat niet op voor internationale organisaties die, ongeacht hoe men een handeling kwalificeert, op basis van verdragen in principe absolute immuniteit van executie (kunnen) genieten.

De vraag of een internationale organisatie handelt in de uitoefening van het openbaar gezag moet uiteindelijk beslecht worden door de nationale rechter, en in dit geval dus de Nederlandse rechter. Tegelijk stelt het Hof van Justitie in redelijk principiële termen vast dat een overeenkomst zoals deze waarop de zaak betrekking heeft, niet valt onder het begrip 'uitoefening van het openbaar gezag'. Deze zienswijze had breder uitgewerkt en beargumenteerd kunnen worden, rekening houdend met andere ontwikkelingen die ik heb aangehaald. Een verdere uitwerking had ook rekening kunnen houden met de specifieke kenmerken van de immuniteit van internationale organisaties die, meer dan in geval van de immuniteit van staten, niet direct gekoppeld kunnen worden aan de vraag of een handeling al dan niet gesteld is in de uitoefening van het openbaar gezag.

53. Voor een overzicht, zie De Brabandere 2019.

54. Zie bijv. C. Ryngaert, 'Immunities of International Organisations before Domestic Courts: Reflections on the Collective Labour Case Against the European Patent Organisation', Netherlands Yearbook of International Law 2015, p. 406.

55. Zie bijv. A. Reinisch en U.A. Weber, 'In the Shadow of Waite and Kennedy: the Jurisdictional Immunity of International Organizations, the Individual's Right of Access to the Courts and Administrative Tribunals as Alternative Means of Dispute Settlement', International Organizations Law Review 2004, p. 63.

56. Supreme Court of Canada 29 april 2016, 2016 SCC 15 (World Bank Group/Wallace), beschikbaar via https://scc-csc.lexum.com/scc-csc/ scc-csc/en/15915/1/document.do (geraadpleegd 9 augustus 2017).

57. Hof 's-Gravenhage 21 juni 2011, ECLI:NL:GHSGR:2011:BR0188 (European Patent Organisation/Stichting Restaurant de la Tour). 